\title{
Numerical Analysis of Novel Back Surface Field for High Efficiency Ultrathin CdTe Solar Cells
}

\author{
M. A. Matin, ${ }^{1}$ M. U. Tomal, ${ }^{1}$ A. M. Robin, ${ }^{1}$ and N. Amin ${ }^{2,3}$ \\ ${ }^{1}$ Department of Electrical and Electronic Engineering, Chittagong University of Engineering and Technology (CUET), \\ Chittagong-4349, Bangladesh \\ ${ }^{2}$ Department of Electrical, Electronic and System Engineering, Universiti Kebangsaan Malaysia (UKM), 43600, Malaysia \\ ${ }^{3}$ Advanced Materials Research Chair, Chemistry Department, College of Sciences, King Saud University, \\ Riyadh 11421, Saudi Arabia \\ Correspondence should be addressed to M. U. Tomal; mayn_tomal@yahoo.com
}

Received 31 May 2013; Revised 24 September 2013; Accepted 24 September 2013

Academic Editor: Leonardo Palmisano

Copyright (C) 2013 M. A. Matin et al. This is an open access article distributed under the Creative Commons Attribution License, which permits unrestricted use, distribution, and reproduction in any medium, provided the original work is properly cited.

\begin{abstract}
This paper numerically explores the possibility of high efficiency, ultrathin, and stable CdTe cells with different back surface field (BSF) using well accepted simulator AMPS-1D (analysis of microelectronics and photonic structures). A modified structure of CdTe based PV cell $\mathrm{SnO}_{2} / \mathrm{Zn}_{2} \mathrm{SnO}_{4} / \mathrm{CdS} / \mathrm{CdTe} / \mathrm{BSF} / \mathrm{BC}$ has been proposed over reference structure $\mathrm{SnO}_{2} / \mathrm{Zn}_{2} \mathrm{SnO}_{4} / \mathrm{CdS} / \mathrm{CdTe} / \mathrm{Cu}$. Both higher bandgap materials like ZnTe and $\mathrm{Cu}_{2} \mathrm{Te}$ and low bandgap materials like $\mathrm{As}_{2} \mathrm{Te}_{3}$ and $\mathrm{Sb}_{2} \mathrm{Te}_{3}$ have been used as $\mathrm{BSF}$ to reduce minority carrier recombination loss at the back contact in ultra-thin CdTe cells. In this analysis the highest conversion efficiency of CdTe based PV cell without BSF has been found to be around $17 \%$ using CdTe absorber thickness of $5 \mu \mathrm{m}$. However, the proposed structures with different BSF have shown acceptable efficiencies with an ultra-thin CdTe absorber of only $0.6 \mu \mathrm{m}$. The proposed structure with $\mathrm{As}_{2} \mathrm{Te}_{3}$ BSF showed the highest conversion efficiency of $20.8 \%\left(V_{\mathrm{oc}}=0.99 \mathrm{~V}, J_{\mathrm{sc}}=24.73 \mathrm{~mA} / \mathrm{cm}^{2}\right.$, and FF $\left.=0.84\right)$. Moreover, the proposed structures have shown improved stability in most extents, as it was found that the cells have relatively lower negative temperature coefficient. However, the cell with ZnTe BSF has shown better overall stability than other proposed cells with temperature coefficient (TC) of $-0.3 \% /{ }^{\circ} \mathrm{C}$.
\end{abstract}

\section{Introduction}

Thin-film polycrystalline CdTe is one of the leading materials for high efficiency, low cost, and stable PV cells. CdTe has a direct bandgap $(\mathrm{Eg}=1.45 \mathrm{eV})$ which is very close to optimum bandgap $(\mathrm{Eg}=1.5 \mathrm{eV})$ for solar cell as discussed by Shockley and Queisser [1]. It has a high absorption coefficient of $5 \times$ $10^{5} / \mathrm{cm}$, which indicates that efficient collection of photons with energy greater than the bandgap $(\mathrm{Eg})$ is possible within a very thin CdTe absorber layer as discussed by Hädrich et al. [2]. Already, the CdTe PV cell has gained a lot of attraction to the researchers and commercials for its low cost, higher efficiency, high stability, and large scale fabrication opportunity as discussed by Bätzner et al. [3]. Commercially available leading CdTe cell has an efficiency of $16.5 \%$ as discussed by $\mathrm{Wu}$ [4]. This cell uses a modified structure of CTO/ZTO/CdS/CdTe/Cu:HgTe:Cu$X$ Te having $10 \mu \mathrm{m} \mathrm{CdTe}$ and $0.1 \mu \mathrm{m}$ CdS layer. Recently First Solar announced a new world record for CdTe photovoltaic (PV) cell having an efficiency of $18.7 \%$ as discussed on the website [5], which is quiet inferior compared to the theoretical maximum efficiency (29\%). This inferiority is primarily caused because the open circuit voltage $\left(V_{\mathrm{oc}}=0.845 \mathrm{~V}\right)$ is well below what is expected for its bandgap $(1.45 \mathrm{eV})$. Another critical issue related to the CdTe solar cell technology is the formation of an efficient, stable, low resistance, and nonrectifying ohmic contact on the p-CdTe layer as discussed by Romeo et al. [6], since CdTe is a p-type semiconductor with a high bandgap $(1.45 \mathrm{eV})$ and high electron affinity $(\chi=4.5 \mathrm{eV})$. Typically a stable ohmic contact to CdTe requires either a metal with a work function of more than $5.7 \mathrm{eV}$ or a sufficiently narrow Schottky barrier to enable tunneling. There is no metal having such high work functions to make good ohmic contacts to p-CdTe; instead they tend to form Schottky or blocking barriers as discussed by Partain [7]. Generally $\mathrm{Cu}$ is used as back contact, but back contacts containing $\mathrm{Cu}$ are not stable; it leads to efficiency 
degradation with time due to $\mathrm{Cu}$ diffusion to the front contact which causes shunting effect as discussed by Batzner et al. [8]. There are many allowed states within the forbidden gap at the back surface in CdTe solar cell, and recombination can efficiently take place through these states. When the minority carrier diffusion length is longer than the cell thickness, back surface recombination may become the primary limitation on cell performance. The use of an electron reflector is a strategy to overcome these obstacles. An electron reflector is a conduction band energy barrier at the back surface of the solar cell, which can reduce the recombination due to the electron flow to the back surface and helps formation of stable back contact. Typical techniques to create an efficient and stable back contact are as follows:

(i) to moderate the width of conduction band barrier height for reflecting the electron by heavily doping an extra layer of back surface field (BSF) with appropriate material;

(ii) to reduce the valence band barrier height between the $\mathrm{CdTe}$ absorber layer and final metal back contact for smooth transition of hole flow to the back contact.

Among these, the use of BSF layers at back surface has been found to be quiet easy and efficient. The importance of BSF layers attracted some attention in the 1980s as discussed elsewhere [9-11]. The BSF layer accommodates the photogenerated minority carriers and keeps them within the reach of the $\mathrm{p}-\mathrm{n}$ junction for efficient collection.

$\mathrm{ZnTe}$ is the most common BSF material. It is a p-type semiconductor having a direct band gap of $2.26 \mathrm{eV}$. Due to its lower work function and the ability to dope it highly ptype, formation of ohmic contacts to ZnTe is much easier. Bätzner et al. at the University of Parma (Italy) has proposed two more potential BSF materials for CdTe solar cells; these are $\mathrm{Sb}_{2} \mathrm{Te}_{3}$ as discussed by Bätzner et al. [3] and $\mathrm{As}_{2} \mathrm{Te}_{3}$ as discussed by Romeo et al. [12]. $\mathrm{Sb}_{2} \mathrm{Te}_{3}(\mathrm{Eg}=0.3 \mathrm{eV})$ and $\mathrm{As}_{2} \mathrm{Te}_{3}(\mathrm{Eg}=0.6 \mathrm{eV})$ both are p-type semiconductor with a low optical band gap. Another potential BSF material is $\mathrm{Cu}_{2} \mathrm{Te}$ which has a moderate band gap of $1.18 \mathrm{eV}$ as discussed by Hossain et al. [13]. Throughout this study using "AMPS1D" simulator, we aimed to achieve higher efficiency using BSF and study the overall effect of zinc telluride (ZnTe), antimony telluride $\left(\mathrm{Sb}_{2} \mathrm{Te}_{3}\right)$, arsenic telluride $\left(\mathrm{As}_{2} \mathrm{Te}_{3}\right)$, and copper telluride $\left(\mathrm{Cu}_{2} \mathrm{Te}\right)$ on cell performance. The effect of temperature variation is also described to understand the environmental effect on the cell performance. This analysis indicates that $\mathrm{As}_{2} \mathrm{Te}_{3}, \mathrm{Sb}_{2} \mathrm{Te}_{3}$, and $\mathrm{Cu}_{2} \mathrm{Te}$ are suitable $\mathrm{BSF}$ materials for higher efficiency $(>19 \%)$ and ultra-thin $(<1 \mu \mathrm{m})$ CdTe cells. However, while considering the performances of the cell, the cell with ZnTe BSF has shown better stability than other cells.

\section{Modeling and Simulation}

The purpose of numerical modeling and simulation in photovoltaic cell analysis is to check the validity of proposed physical structures maintaining cell geometry and cell performance. The AMPS-1D program has been developed to visualize the details of the physical operation of solar cells. The simulator has also been tested for thin film CIGS and CdTe solar cells as discussed by Degrave et al. [14]. It perfectly simulates the electrical characteristics of the thin film heterojunction solar cells. Recently, more than 200 groups worldwide have been using AMPS-1D in order to design solar cell as discussed by Zhu et al. [15]. Onedimensional AMPS-1D simulator has been used to investigate the effect of different BSF on ultra-thin CdTe solar cell.

The baseline structure of CdTe cell as discussed by Gloeckler et al. [16] was initially modified by adding an extra layer of $\mathrm{Zn}_{2} \mathrm{SnO}_{4}(200 \mathrm{~nm})$ between $\mathrm{SnO}_{2}$ (TCO) and CdS layer. The additional layer of high-resistiance $\mathrm{Zn}_{2} \mathrm{SnO}_{4}$ is known as buffer layer. By incorporating a very thin resistive buffer layer, the CdS layer thickness can be further reduced down to $<50 \mathrm{~nm}$, which significantly improves the blue response, CdS film morphology, and conversion efficiency of the CdTe solar cell as discussed by Morales-Acevedo [17]. The structure $\mathrm{SnO}_{2} / \mathrm{Zn}_{2} \mathrm{SnO}_{4} / \mathrm{CdS} / \mathrm{CdTe} / \mathrm{Cu}$ shown in Figure 1(a) has been taken as reference structure for this study with CdS thickness of $60 \mathrm{~nm}$.

The reference cell has been further modified to Glass/ $\mathrm{SnO}_{2} / \mathrm{Zn}_{2} \mathrm{SnO}_{4} / \mathrm{CdS} / \mathrm{CdTe} / \mathrm{BSF} / \mathrm{Metal}$ structure for higher conversion efficiency, shown in Figure 1(b). BSF layers have been added to overcome rollover effect, to improve stability at higher operating temperature, and to reduce the loss due to minority carrier recombination at the back contact in ultra-thin CdTe cells. BSF materials used in this study are zinc telluride $(\mathrm{ZnTe})$, antimony telluride $\left(\mathrm{Sb}_{2} \mathrm{Te}_{3}\right)$, arsenic telluride $\left(\mathrm{As}_{2} \mathrm{Te}_{3}\right)$, and copper telluride $\left(\mathrm{Cu}_{2} \mathrm{Te}\right)$. For the low cost aspect, cheaper metal ( $\mathrm{Ni}, \mathrm{Cu}$, and $\mathrm{Mo}$ ) has been used as final back contact in the proposed structure. The doping concentration (up to $10^{14} \mathrm{~cm}^{-3}$ ) used in the reference case has been changed to up to $10^{16} \mathrm{~cm}^{-3}$ as it is the present achievable value for CdTe material. To understand the stability of the cell, the operating temperature has been changed from $25^{\circ} \mathrm{C}$ to $100^{\circ} \mathrm{C}$.

Table 1 shows the significant material parameters used in this modeling. The values of Table 1 were selected from standard literatures and from theoretical and practically variable values. The reference structure was the starting point of the analysis. In this modeling, the CdTe absorber layer thickness has been varied from $100 \mathrm{~nm}$ to up to $5 \mu \mathrm{m}$; all other layers thickness has been kept constant.

\section{Results and Discussion}

3.1. Reference Cell Simulation. The cell shown in Figure 1(a) also mentioned as reference cell has been analyzed initially. The reference cell has shown the highest conversion efficiency of $16.88 \%\left(V_{\mathrm{oc}}=0.895 \mathrm{~V}, J_{\mathrm{sc}}=25.10 \mathrm{~mA} / \mathrm{cm}^{2}\right.$, and $\mathrm{FF}=$ 0.75) where layer thickness of CdTe is $5 \mu \mathrm{m}$, layer thickness of CdS is $60 \mathrm{~nm}$, and layer thickness of $\mathrm{Zn}_{2} \mathrm{SnO}_{4}$ is $200 \mathrm{~nm}$ and $\mathrm{Cu}$ has been used as the back contact metal. CdTe doping concentration $\left(5 \times 10^{16}\right)$ and life time $(1.6 \mathrm{~ns})$ have been adopted which is the today's achievable limit as discussed by Amin et al. [18]. 


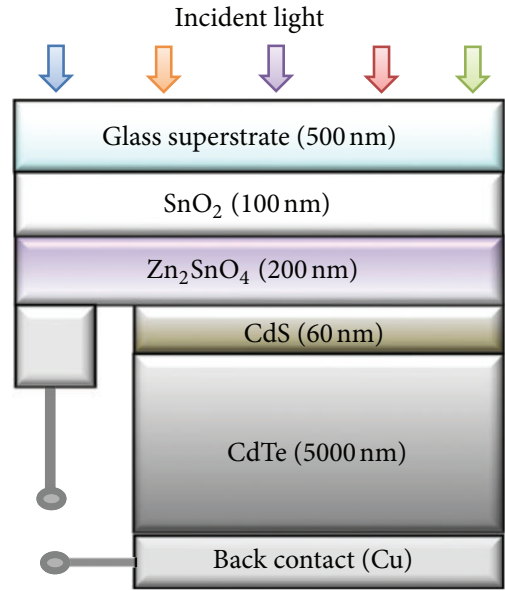

(a)

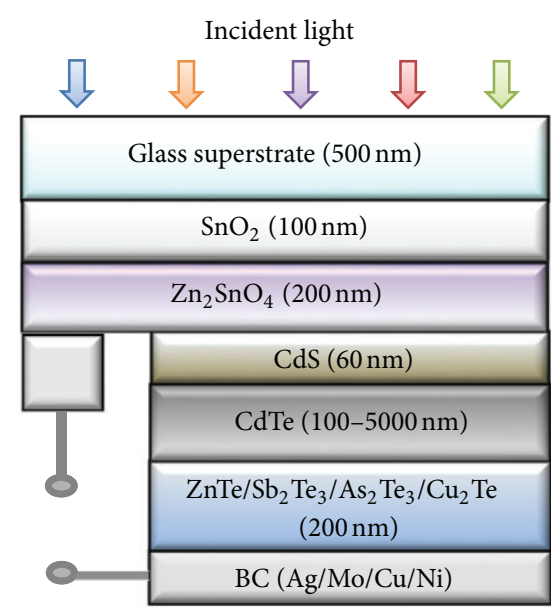

(b)

Figure 1: Structures of the CdTe solar cells: (a) reference structure, (b) proposed structure for higher performance.

TABLE 1: Material parameters used in simulation.

\begin{tabular}{|c|c|c|c|c|c|c|}
\hline Parameter & $\mathrm{n}-\mathrm{SnO}_{2}$ & $\begin{array}{c}\mathrm{n}- \\
\mathrm{Zn}_{2} \mathrm{SnO}_{4} \\
\end{array}$ & n-CdS & $\mathrm{p}-\mathrm{CdTe}$ & $\mathrm{ZnTe} / \mathrm{As}_{2} \mathrm{Te}_{3} / \mathrm{Sb}_{2} \mathrm{Te}_{3} / \mathrm{Cu}_{2} \mathrm{Te}$ & $\begin{array}{l}\text { Comments and } \\
\text { references }\end{array}$ \\
\hline Thickness $(\mu \mathrm{m})$ & 0.1 & 0.2 & 0.06 & $0.1-5.0$ & 0.2 & Theory and estimations \\
\hline Dielectric constant, $\varepsilon / \varepsilon_{0}$ & 9.0 & 9.0 & 10.0 & 9.4 & $14 / 20 / 55 / 10$ & $\begin{array}{c}\text { As discussed elsewhere } \\
{[3,12,16,20,21]}\end{array}$ \\
\hline Electron mobility, $\mu \mathrm{e}\left(\mathrm{cm}^{2} / \mathrm{Vs}\right)$ & 100 & 32 & 100 & 320 & $70 / 500 / 1094 / 500$ & $\begin{array}{c}\text { As discussed elsewhere } \\
{[12,16,18,21,22]}\end{array}$ \\
\hline Hole mobility, $\mu \mathrm{p}\left(\mathrm{cm}^{2} / \mathrm{Vs}\right)$ & 25 & 03 & 25 & 40 & $50 / 210 / 320 / 100$ & $\begin{array}{c}\text { As discussed elsewhere } \\
{[13,16,18,21,22]}\end{array}$ \\
\hline $\begin{array}{l}\text { Electron and hole concentration, } \\
\mathrm{n}, \mathrm{p}\left(\mathrm{cm}^{-3}\right)\end{array}$ & $10^{17}$ & $10^{19}$ & $10^{17}$ & $5 \times 10^{15}$ & $\begin{array}{c}10^{21}\left(\mathrm{Cu}_{2} \mathrm{Te}\right) / 7.5 \times 10^{19} \\
\text { (Others) }\end{array}$ & $\begin{array}{c}\text { As discussed elsewhere } \\
{[13,16,19,21,23]}\end{array}$ \\
\hline Bandgap, Eg (eV) & 3.6 & 3.35 & 2.42 & 1.45 & $2.25 / 0.6 / 0.3 / 1.18$ & $\begin{array}{l}\text { As discussed elsewhere } \\
\quad[10,13,16,22,23]\end{array}$ \\
\hline $\begin{array}{l}\text { Density of states at conduction } \\
\text { band, NC }\left(\mathrm{cm}^{-3}\right)\end{array}$ & $2.2 \times 10^{18}$ & $2.0 \times 10^{18}$ & $2.2 \times 10^{18}$ & $8.0 \times 10^{17}$ & $7.8 \times 10^{17}$ & $\begin{array}{c}\text { As discussed elsewhere } \\
{[16,19,21,23,24]}\end{array}$ \\
\hline $\begin{array}{l}\text { Density of states at valence band, } \\
\mathrm{NV}\left(\mathrm{cm}^{-3}\right)\end{array}$ & $1.8 \times 10^{19}$ & $1.5 \times 10^{19}$ & $1.8 \times 10^{19}$ & $1.8 \times 10^{19}$ & $1.6 \times 10^{19}$ & $\begin{array}{c}\text { As discussed elsewhere } \\
{[16,19,21,23,24]}\end{array}$ \\
\hline Electron affinity, $\chi(\mathrm{eV})$ & 4.50 & 4.50 & 4.50 & 4.28 & $3.65 / 4 / 4.15 / 4.20$ & $\begin{array}{c}\text { As discussed elsewhere } \\
{[16,18,19,21-24]}\end{array}$ \\
\hline
\end{tabular}

Theoretically a $2 \mu \mathrm{m}$ thick CdTe layer is efficient to absorb 99\% of the incident photons with energy greater than Eg as discussed by $\mathrm{Wu}$ [4]. Although to avoid pinhole formation and uniformity limitation, in most high efficiency CdTe solar cells, the CdTe absorber layer is intentionally set at a minimum thickness of $5 \mu \mathrm{m}$. Further numerical analysis has been done using AMPS-1D to reduce the thickness of CdTe layers aiming to reduce the materials usages and cell production cost. The CdTe absorber thickness has been varied from $100 \mathrm{~nm}$ to $5000 \mathrm{~nm}$ for both reference and modified cells to explore possibilities of ultra-thin CdTe absorber layer. The simulated results are graphically shown in Figure 2.

Figure 2 shows that, for the reference cell, all the solar cell output parameters are unaffected for the CdTe thickness of greater than $2 \mu \mathrm{m}$ and nearly affected around CdTe thickness of $1 \mu \mathrm{m}$. Further reduction of CdTe thickness below $1 \mu \mathrm{m}$ shows that, with reduced thickness, $J_{\mathrm{sc}}$ and $V_{\mathrm{oc}}$ decreased slowly while FF increased below $500 \mathrm{~nm}$. The $J_{\mathrm{sc}}$ decreases sharply at CdTe thickness of less than $0.5 \mu \mathrm{m}$ due to critically short minority carrier diffusion length, but FF shows an increased value due to the bulk resistance reduction. All these effects result in reduction of cell conversion efficiency for $\mathrm{CdTe}$ absorber thickness below $1 \mu \mathrm{m}$. These results are in good agreement with related published works for CdTe cells as discussed by Amin et al. [18]. So having a thin CdTe layer for the reference cell is not possible while maintaining higher conversion efficiency. However, there are possibilities of increasing $V_{\mathrm{oc}}, J_{\mathrm{sc}}$, and FF below CdTe thickness of $1 \mu \mathrm{m}$ while having improved efficiency. In order to attain this goal the reference structure has been modified with a layer of BSF $(200 \mathrm{~nm})$ just after the CdTe layer. The proposed structure has been shown in Figure 1(b). 

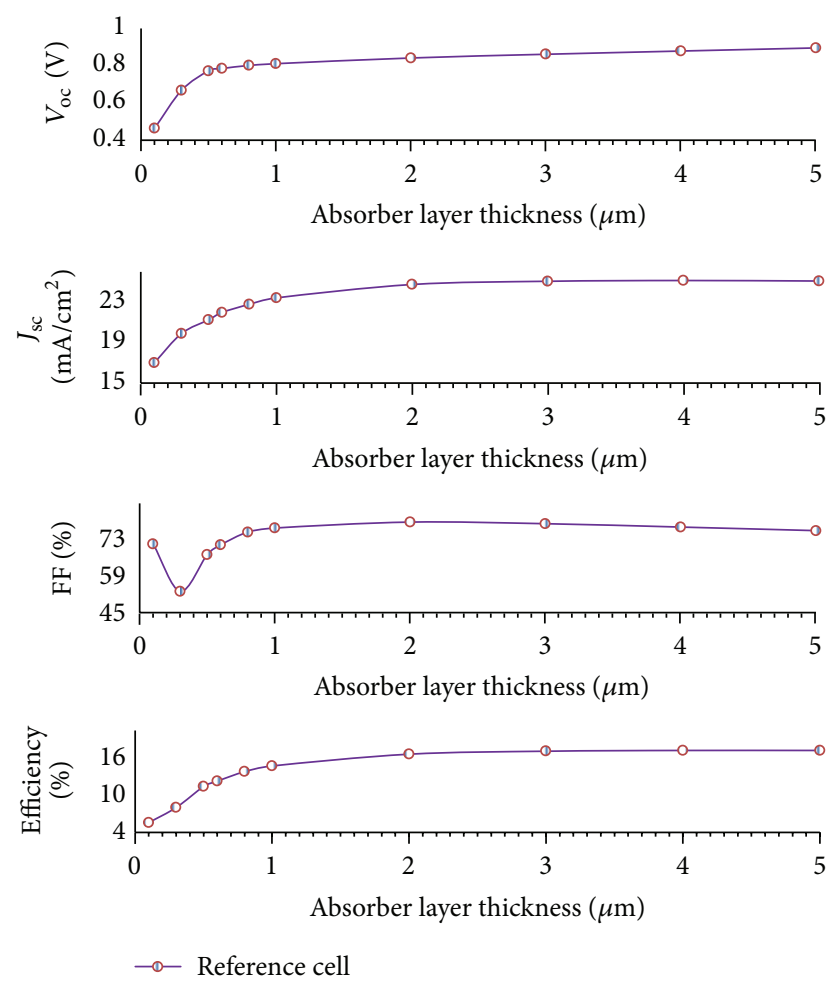

FIGURE 2: Effect of CdTe thickness layer variation on reference cell parameters and proposed cell parameter.

\subsection{Effect of BSF on Reference Cell Output Parameters}

3.2.1. Effect of BSF on Short Circuit Current Density $J_{s c}$. Figure 3 graphically interprets the effect of different BSF layers on the proposed structure. The simulated figure shows that BSF has significant effect on proposed cell as it shows increase in short circuit current $J_{\mathrm{sc}}$ in small scale. The effect of BSF is quiet significant, while the absorber thickness is below $1 \mu \mathrm{m}$. Here BSF works as a minority carrier reflector and reduces the minority carrier recombination at back contact. As there are more carriers to contribute to $J_{\mathrm{sc}}$, the use of BSF certainly improves cell short circuit current density. This is in a good agreement with previous work [18]. As shown above in Figure 3 the cell with zinc telluride (ZnTe) as BSF has shown most significance in improving $J_{\mathrm{sc}}$ for absorber thickness of up to $0.5 \mu \mathrm{m}$, whereas $\mathrm{As}_{2} \mathrm{Te}_{3}, \mathrm{Cu}_{2} \mathrm{Te}$, and $\mathrm{Sb}_{2} \mathrm{Te}_{3}$ have shown steady, improved $J_{s c}$ with variation of absorber thickness and are almost identical to each other. From the results it is evident that, with a BSF layer, a reasonable $J_{s c}$ can be maintained while having an absorber thickness below $1 \mu \mathrm{m}$.

\subsubsection{Effect of Back Surface Field on Open Circuit Voltage.}

Numerical analysis has been done with the proposed ultra-thin cell structure $\mathrm{SnO}_{2} / \mathrm{Zn}_{2} \mathrm{SnO}_{4} / \mathrm{CdS} / \mathrm{CdTe} / \mathrm{BSF} / \mathrm{BC}$ aiming to explore the effect of different $\mathrm{BSF}$ materials on open circuit voltage $V_{\mathrm{oc}}$. For realizing the effect of BSF on modified $\mathrm{CdTe}$ cell open circuit voltage for different BSF materials is represented graphically taking the base cell parameters as reference with a variable absorber layer thickness in Figure 4.

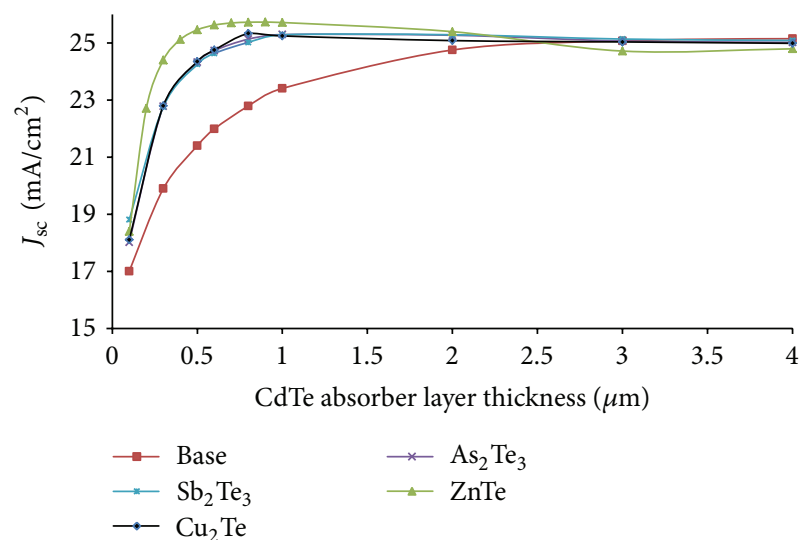

FIGURE 3: Effect of different BSF on cell short circuit current density on proposed cell with variable absorber thickness.

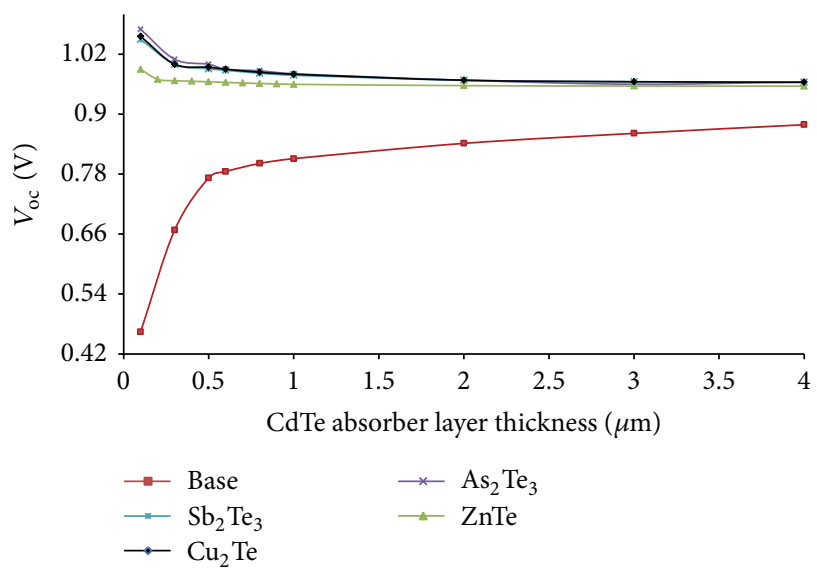

FIGURE 4: Effect of different BSF on cell open circuit voltage on proposed cell with variable absorber thickness.

The effect of back surface material on open circuit voltage is found when CdTe layer thickness is $<2 \mu \mathrm{m}$. Considerable impact is found by reducing CdTe absorber thickness below $1 \mu \mathrm{m}$. As in Figure 4 it can be seen that $V_{\text {oc }}$ is improved significantly below CdTe layer thickness of $1 \mu \mathrm{m}$. This might be attributed to the reduction of the minority carrier recombination losses at the back contact in ultra-thin CdTe cell. In improving $V_{\mathrm{oc}}$, uses of arsenic telluride $\left(\mathrm{As}_{2} \mathrm{Te}_{3}\right)$ as BSF have shown more significance than $\mathrm{ZnTe}, \mathrm{Sb}_{2} \mathrm{Te}_{3}$, and $\mathrm{Cu}_{2} \mathrm{Te}$, while $\mathrm{Sb}_{2} \mathrm{Te}_{3}$ and $\mathrm{Cu}_{2}$ Te have shown almost the same effect on $V_{\text {oc }}$. It is significant that a desired improvement in $V_{\text {oc }}$ is possible although the absorber is reduced below $1 \mu \mathrm{m}$ with just a $200 \mathrm{~nm}$ of BSF layer.

3.2.3. Effect of Back Surface Field on Field Factor, FF. The fill Factor also gets some changes due to the use of BSF materials. Fill factor increases with the reduction of absorber layer thickness as bulk resistance of materials has been reduced. As shown in Figure 5.

The cell with antimony telluride $\left(\mathrm{Sb}_{2} \mathrm{Te}_{3}\right)$ as BSF has most significant effect on fill factor. Use of antimony telluride $\left(\mathrm{Sb}_{2} \mathrm{Te}_{3}\right)$ as BSF increases fill factor below absorber thickness 


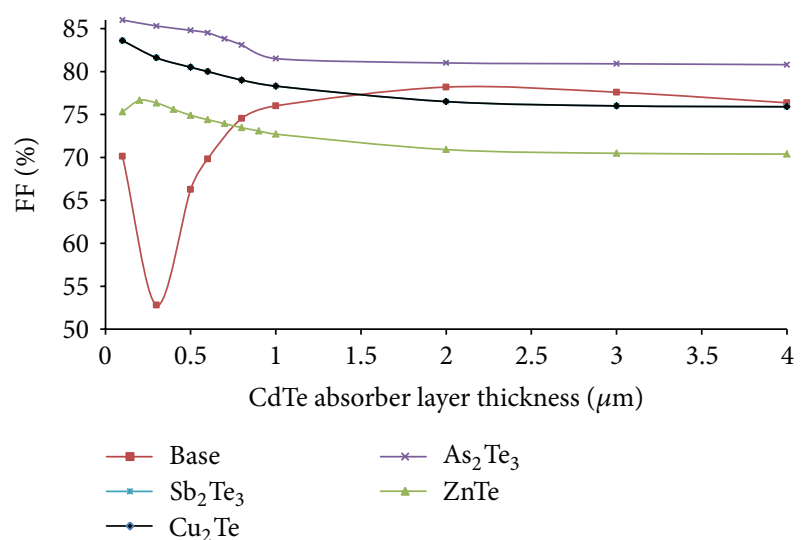

FIGURE 5: Effect of different BSF on cell fill factor on proposed cell with variable absorber thickness.

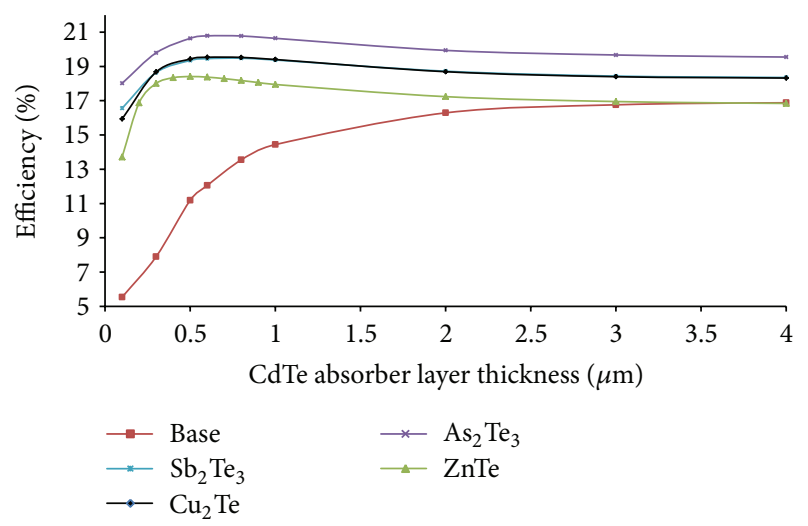

FIGURE 6: Effect of different BSF on cell overall efficiency on proposed cell with variable absorber thickness.

of $1 \mu \mathrm{m}$ but shows a decreased value for greater absorber layer thickness. For $\mathrm{As}_{2} \mathrm{Te}_{3}, \mathrm{Cu}_{2} \mathrm{Te}$, and $\mathrm{ZnTe}$ fill factor slightly increases, while the absorber thickness is below $1 \mu \mathrm{m}$.

\subsubsection{Effect of Back Surface Field on Overall Cell Efficiency.} The effect of different BSF materials on overall conversion efficiency of modified CdTe cell has also been analyzed using AMPS-1D simulator for the proposed ultra-thin CdTe PV cell. The effect of BSF on overall cell conversion efficiency is represented graphically along the reference cell efficiency with a variable absorber layer thickness in Figure 6.

It is evident from Figure 6 that, when ZnTe is inserted as a BSF, the conversion efficiency does not improve significantly. Although the FF of the cell with $\mathrm{ZnTe}$, as shown in Figure 5, was strongly affected, the $J_{\text {sc }}$ improved as shown in Figure 3 a bit due to reduced minority carrier recombination loss at the back contact. It is clear from band diagram of the cells that the ZnTe has shown a barrier at the valence band of CdTe and $\mathrm{ZnTe}$ interface. The reduction in FF might be attributed to the barrier developed for holes in the valence band. These results are in good agreement with what was discussed by Amin et al. [18]. All in all, the decrease in FF dominates over the increase of $J_{\mathrm{sc}}$; as a result there is no significant improvement in the cell overall efficiency when ZnTe is used as BSF.

When $\mathrm{Sb}_{2} \mathrm{Te}_{3}, \mathrm{As}_{2} \mathrm{Te}_{3}$, and $\mathrm{Cu}_{2} \mathrm{Te}$ were inserted as BSF, the conversion efficiency improved significantly with reduced absorber thickness. The improvement in efficiency of this cell came from the improvement of all the cell output parameters like FF, $V_{\mathrm{oc}}$, and $J_{\mathrm{sc}}$, as shown in the figures earlier. From Figure 6 it is also seen that back surface material affects cell conversion efficiency significantly when CdTe layer thickness is $<1 \mu \mathrm{m}$. It is evident that the $\mathrm{As}_{2} \mathrm{Te}_{3} \mathrm{BSF}$ has shown the highest improvement on conversion efficiency as shown in previous figure. $\mathrm{Sb}_{2} \mathrm{Te}_{3}$ and $\mathrm{Cu}_{2} \mathrm{Te}$ have shown moderate improvement on cell conversion efficiency. The most important thing to be noted from Figure 6 is that the efficiency limitation with reduced absorber layer thickness discussed earlier has been overcome by the insertion of just $0.02 \mu \mathrm{m}$ thin BSF layer.

3.2.5. I-V Characteristics with Back Surface Field on Cell. I-V $(J-V)$ characteristic of a solar cell refers to the combined effect of series resistance and shunt resistance. For the better performance of solar cell higher shunt resistance is desirable, but higher series resistance is not acceptable as it might decrease the fill factor. The BSF material has great influence in $I-V$ characteristics, as shown in Figure 7. From the figure it is seen that the base cell $I-V$ curve starts rolling down around $V_{\mathrm{oc}}=0.6 \mathrm{~V}$ and shows maximum power at a lower value for $V_{\text {oc }}$ between $0.7 \mathrm{~V}$ to $0.8 \mathrm{~V}$. But modified cell with BSF has shown noticeable increased value and better performance than base cell.

As can be seen in the figure, the structure with BSF shows higher $V_{\text {oc }}$ than the cell without BSF, while the cell with ZnTe shows higher $J_{\mathrm{sc}}$ but poor FF. The FF is affected because of the higher series resistance added by the bulk resistance of the higher bandgap and the barrier for holes in the valence band and lower dielectric property of the ZnTe material. The cells with $\mathrm{Sb}_{2} \mathrm{Te}_{3}$ and $\mathrm{Cu}_{2} \mathrm{Te}$ have shown moderate effect of parasitic resistance on its output parameters. In this analysis arsenic telluride $\left(\mathrm{As}_{2} \mathrm{Te}_{3}\right)$ has shown improved performances better than others and obtains $I-V$ curve almost identical to ideal $I-V$ curve with a negligible effect from parasitic resistances.

3.2.6. Effect of Back Surface Field on Cell Stability. Before finalizing any conclusion, the stability of the proposed cell at higher operating temperature has been investigated. Theoretically, it is expected that higher operating temperature affects cell parameters such as the band gaps, carrier concentrations, density of states, and electron and hole mobility. Similar results have also been found in this analysis. An investigation was conducted utilizing AMPS-1D at operating temperature ranging from $25^{\circ} \mathrm{C}$ to $100^{\circ} \mathrm{C}$ for the proposed cells. The results obtained from AMPS-1D simulation are shown in Figure 8.

The figure indicates that the conversion efficiency of both reference and proposed cells linearly decreased with the increase of operating temperature. The temperature coefficient (TC) of reference cell is found to be $-0.4 \% /{ }^{\circ} \mathrm{C}$, which is in good agreement with theoretical evidences and 
TABLE 2: Output parameters of different cells with BSF for maximum efficiency.

\begin{tabular}{lcccccc}
\hline Different cell structures & $\begin{array}{c}\text { Optimum CdTe layer } \\
\text { thickness }(\mu \mathrm{m})\end{array}$ & $V_{\text {oc }}(\mathrm{V})$ & $J_{\text {sc }}\left(\mathrm{mA} / \mathrm{cm}^{2}\right)$ & FF & Eff. (\%) & Temp. coefficient $\left(\%{ }^{\circ} \mathrm{C}\right)$ \\
\hline $\mathrm{SnO}_{2} / \mathrm{Zn}_{2} \mathrm{SnO}_{4} / \mathrm{CdS} / \mathrm{CdTe} / \mathrm{Cu}$ & 5.0 & 0.895 & 25.10 & 75.0 & 16.88 & $-0.4 \%$ \\
$\mathrm{SnO}_{2} / \mathrm{Zn}_{2} \mathrm{SnO}_{4} / \mathrm{CdS} / \mathrm{CdTe} / \mathrm{ZnTe} / \mathrm{Ag}$ & 0.6 & 0.96 & 25.63 & 74.4 & 18.37 & $-0.3 \%$ \\
$\mathrm{SnO}_{2} / \mathrm{Zn}_{2} \mathrm{SnO}_{4} / \mathrm{CdS} / \mathrm{CdTe} / \mathrm{Sb}_{2} \mathrm{Te}_{3} / \mathrm{Mo}$ & 0.6 & 0.98 & 24.63 & 80.0 & 19.45 & $-0.4 \%$ \\
$\mathrm{SnO}_{2} / \mathrm{Zn}_{2} \mathrm{SnO}_{4} / \mathrm{CdS} / \mathrm{CdTe} / \mathrm{As}_{2} \mathrm{Te}_{3} / \mathrm{Cu}$ & 0.6 & 0.99 & 24.73 & 84.5 & 20.78 & $-0.4 \%$ \\
$\mathrm{SnO}_{2} / \mathrm{Zn}_{2} \mathrm{SnO}_{4} / \mathrm{CdS} / \mathrm{CdTe} / \mathrm{Cu}_{2} \mathrm{Te} / \mathrm{Ni}$ & 0.6 & 0.99 & 24.73 & 79.8 & 19.54 & $-0.35 \%$ \\
\hline
\end{tabular}

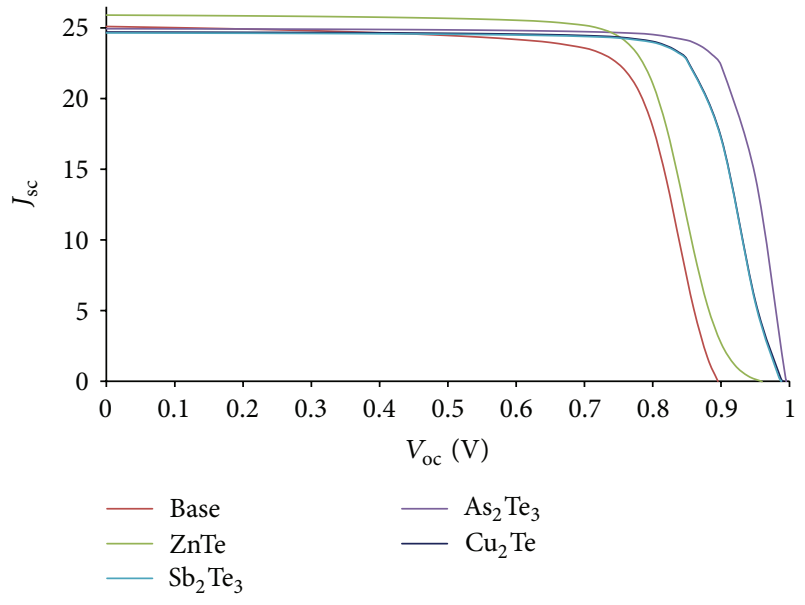

FIGURE 7: $I-V$ curve of base cell and modified cell.

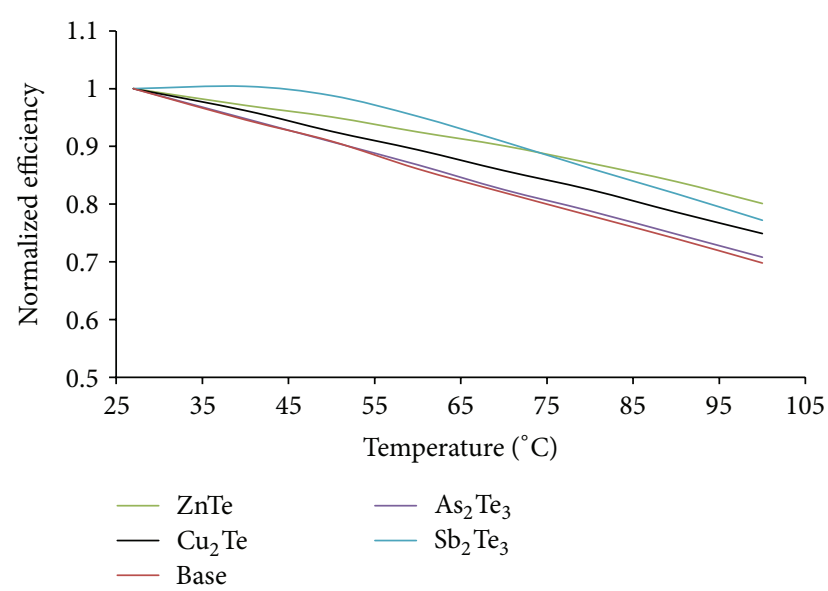

FIGURE 8: Effect of operating temperature on the proposed cell performance.

related works as discussed elsewhere [13, 18, 19]. Moreover, Cells with $\mathrm{Sb}_{2} \mathrm{Te}_{3}$ give better stability as its efficiency remains almost unchanged in the operating temperature range from $25^{\circ} \mathrm{C}$ to $50^{\circ} \mathrm{C}$, and then it decreases with a TC of $-0.4 \% /{ }^{\circ} \mathrm{C}$. The stability of cell with $\mathrm{As}_{2} \mathrm{Te}_{3}$ showed the same stability of the cell without BSF. Thus, the $\mathrm{As}_{2} \mathrm{Te}_{3}$ has no effects on the cell stability at higher operating temperature. The cell with $\mathrm{Cu}_{2} \mathrm{Te}$ has shown improved stability more than the cell without BSF as the temperature coefficient (TC) is found to be around
$-0.35 \% /{ }^{\circ} \mathrm{C}$, whereas the cell with $\mathrm{ZnTe}$ showed better stability with $\mathrm{TC}$ of $-0.3 \% /{ }^{\circ} \mathrm{C}$.

\section{Comparison of Different BSF in Ultrathin CdTe Cells}

By analysing all the graphs of different BSF materials from the previous sections it is evident that they all have similar effect on cell performance. But the numerical value of different performance parameter varies for different BSF material. Maximum efficiencies of different proposed structures with the optimum CdTe layer thickness are listed on Table 2.

Maximum conversion efficiency of cells with different BSF is found for CdTe thickness of just $0.6 \mu \mathrm{m}$. It is also found from Table 2 that in the proposed cell with ZnTe as a BSF the conversion efficiency (18.37\%) drops more than the reference cell as the FF was strongly affected, but the $J_{\text {sc }}$ improved a bit due to reduced minority carrier recombination loss at the back contact. The reduction in FF might be attributed to the band defect in $\mathrm{ZnTe}$ structure. When $\mathrm{Sb}_{2} \mathrm{Te}_{3}$ was inserted as BSF layer, the FF and conversion efficiency improved better than that of $\mathrm{ZnTe} \mathrm{BSF}$. The $\mathrm{As}_{2} \mathrm{Te}_{3}$ BSF produced best cell performances and highest conversion efficiency of $20.78 \%$. The improvement in efficiency of this cell came from the improvement of all the cell output parameters like FF, $V_{\text {oc }}$, and $J_{\text {sc }}$. Use of $\mathrm{Cu}_{2} \mathrm{Te}$ results in a moderate conversion efficiency of $19.54 \%$. Figure 9 shows the band diagram for different proposed structures.

\section{Conclusion}

It has been seen that, without BSF, thinning is not possible while maintaining higher efficiency. Most important thing to be noted from the results is that the efficiency limitation with reduced absorber layer thickness has been overcome by the insertion of $200 \mathrm{~nm}$ thin BSF layer. From the analysis it is evident that $0.6 \mu \mathrm{m}$ thick CdTe absorber layer is possible with acceptable range of efficiency for the proposed structure with BSF. A highly efficient (20.78\%) $\left(V_{\mathrm{oc}}=0.99 \mathrm{~V}, J_{\mathrm{sc}}=24.73 \mathrm{~mA} / \mathrm{cm}^{2}\right.$, and $\left.\mathrm{FF}=0.84\right)$ ultrathin CdTe solar cell with $0.6 \mu \mathrm{m}$ of CdTe, $100 \mathrm{~nm} \mathrm{SnO}_{2}$, $200 \mathrm{~nm}$ of $\mathrm{Zn}_{2} \mathrm{SnO}_{4}, 60 \mathrm{~nm}$ of CdS, and $200 \mathrm{~nm}$ of $\mathrm{As}_{2} \mathrm{Te}_{3}$ has been obtained. $\mathrm{Sb}_{2} \mathrm{Te}_{3}$ and $\mathrm{Cu}_{2} \mathrm{Te}$ as $\mathrm{BSF}$ are suitable for higher efficiency (>19\%) and ultra-thin CdTe cell. Cells with $\mathrm{ZnTe}$ have shown comparatively inferior performance with an efficiency of $18.37 \%$. Cells with $\mathrm{Sb}_{2} \mathrm{Te}_{3}$ gives improved stability as its efficiency remains almost unchanged in the 


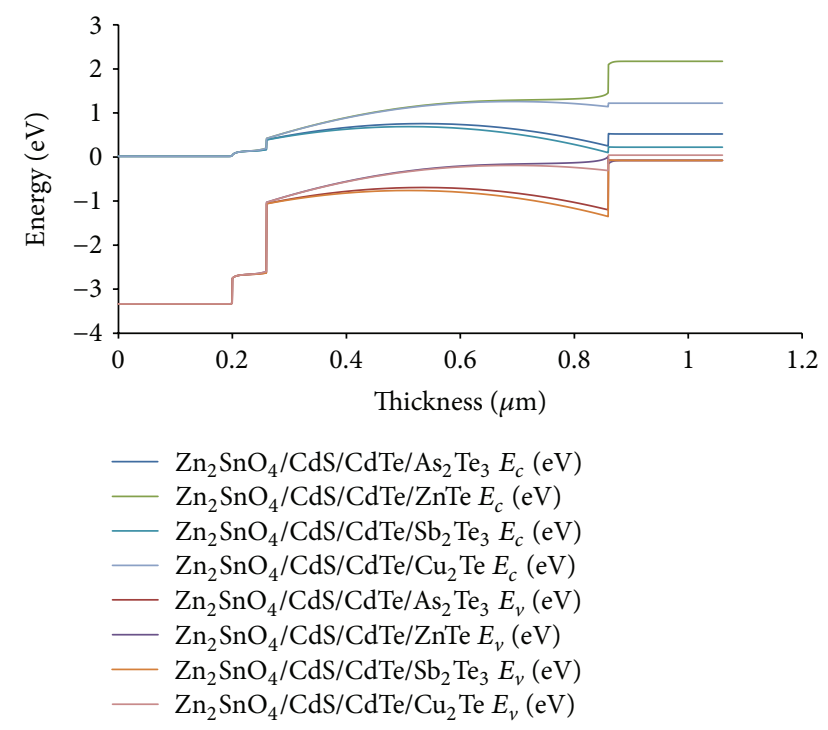

FIGURE 9: Band diagram of the proposed cells $\left(\mathrm{Zn}_{2} \mathrm{SnO}_{4} / \mathrm{CdS} / \mathrm{CdTe} /\right.$ BSF).

operating temperature range from $25^{\circ} \mathrm{C}$ to $50^{\circ} \mathrm{C}$, and then it decreases with a $\mathrm{TC}$ of $-0.4 \% /{ }^{\circ} \mathrm{C}$. The cell with $\mathrm{Cu}_{2} \mathrm{Te}$ shows moderate stability with $\mathrm{TC}$ of $-0.35 \% /{ }^{\circ} \mathrm{C} . \mathrm{As}_{2} \mathrm{Te}_{3}$ has no effect on stability as the TC is same as that of the reference cell. Although cell with $\mathrm{ZnTe}$ is the most stable cell, but while considering efficiency and stability, structures with $\mathrm{SnO}_{2} / \mathrm{Zn}_{2} \mathrm{SnO}_{4} / \mathrm{CdS} / \mathrm{CdTe} / \mathrm{As}_{2} \mathrm{Te}_{3} / \mathrm{Cu}$ are proven to be comparable to other reported cells.

These results could open new window for ultra-thin CdTe cell development and possibly lead to some improvement like: thinner absorber layer with significant performance, reduced material consumption for cell fabrication, and reduced cell fabrication cost; low cost materials $(\mathrm{Cu}$, $\mathrm{Al}$, and $\mathrm{Ni}$ ) could be used as final back contact without interrupting cell performance and stability. In order to realize the possibilities, this proposed cell can further be investigated using standard fabrication technique for practical implementation.

\section{References}

[1] W. Shockley and H. J. Queisser, "Detailed balance limit of efficiency of p-n junction solar cells," Journal of Applied Physics, vol. 32, no. 3, pp. 510-519, 1961.

[2] M. Hädrich, C. Kraft, C. Löffler, H. Metzner, U. Reislöhner, and W. Witthuhn, "Pathways to thin absorbers in CdTe solar cells," Thin Solid Films, vol. 517, no. 7, pp. 2282-2285, 2009.

[3] D. L. Bätzner, A. Romeo, H. Zogg, R. Wendt, and A. N. Tiwari, "Development of efficient and stable back contacts on CdTe/CdS solar cells," Thin Solid Films, vol. 387, no. 1-2, pp. 151154, 2001.

[4] X. Wu, "High-efficiency polycrystalline CdTe thin-film solar cells," Solar Energy, vol. 77, no. 6, pp. 803-814, 2004.

[5] 2013, http://investor.firstsolar.com/releasedetail.cfm?ReleaseID $=743398$.
[6] N. Romeo, A. Bosio, R. Tedeschi, A. Romeo, and V. Canevari, "Highly efficient and stable CdTe/CdS thin film solar cell," Solar Energy Materials and Solar Cells, vol. 58, no. 2, pp. 209-218, 1999.

[7] L. D. Partain, Solar Cells and Their Applications, John Wiley \& Sons, New York, NY, USA, 1995.

[8] D. L. Bätzner, R. Wendt, A. Romeo, H. Zogg, and A. N. Tiwari, "Effect of back contact metallization on the stability of CdTe/ CdS solar cells," in Proceedings of the 16th European Photovoltaic Solar Energy Conference and Exhibition, p. 353, Glasgow, UK, May 2000.

[9] R. P. Gale, J. C. C. Fan, G. W. Turner, and R. L. Chapman, "A new high-efficiency GaAs solar cell structure using a heterostructure back-surface field," in Proceedings of the 17th IEEE Photovoltaic Specialists Conference, pp. 1422-1425, New York, NY, USA, 1984.

[10] P. D. Demoulin, M. S. Lundstrom, and R. J. Schwartz, "Backsurface field design for $\mathrm{n}(+) \mathrm{p}$ GaAs cells," Solar Cells, vol. 20, no. 3, pp. 229-236, 1987.

[11] P. D. DeMoulin and M. S. Lundstrom, "Projections of GaAs solar-cell performance limits based on two-dimensional numerical simulation," IEEE Transactions on Electron Devices, vol. 36, no. 5, pp. 897-905, 1989.

[12] N. Romeo, A. Bosio, S. Mazzamuto, A. Romeo, and L. VaillantRoca, "High efficiency CdTe/CdS thin film solar cells with a novel back contact," in Proceedings of the 22nd European Photovoltaic Solar Energy Conference, pp. 1919-1927, Milan, Italy, 2007.

[13] M. D. S. Hossain, N. Amin, M. A. Matin, M. M. Mannir Aliyu, T. Razykov, and K. Sopian, "A numerical study on the prospects of high efficiency ultra thin ZnxCd1-xS/CdTe solar cell," Chalcogenide Letters, vol. 8, no. 4, pp. 263-272, 2011.

[14] S. Degrave, M. Burgelman, and P. Nollet, "Modelling of polycrystalline thin film solar cells: new features in scaps version 2.3," in Proceddings of the 3rd World Conference on Photovoltaic Energy Conversion, pp. 487-490, May 2003.

[15] H. Zhu, A. K. Kalkan, J. Hou, and S. J. Fonash, "Applications of AMPS-1D for solar cell simulation," AIP Conference Proceedings, vol. 462, pp. 309-314, 1999.

[16] M. Gloeckler, A. L. Fahrenbruch, and J. R. Sites, "Numerical modeling of CIGS and CdTe solar cells: setting the baseline," in Proceddings of the 3rd World Conference on Photovoltaic Energy Conversion, pp. 491-494, May 2003.

[17] A. Morales-Acevedo, "Thin film CdS/CdTe solar cells: research perspectives," Solar Energy, vol. 80, no. 6, pp. 675-681, 2006.

[18] N. Amin, M. A. Matin, M. M. Aliyu, M. A. Alghoul, M. R. Karim, and K. Sopian, "Prospects of back surface field effect in ultra-thin high-efficiency CdS/CdTe solar cells from numerical modeling," International Journal of Photoenergy, vol. 2010, Article ID 578580, 8 pages, 2010.

[19] M. A. Matin, M. M. Aliyu, A. H. Quadery, and N. Amin, "Prospects of novel front and back contacts for high efficiency cadmium telluride thin film solar cells from numerical analysis," Solar Energy Materials and Solar Cells, vol. 94, no. 9, pp. 14961500, 2010.

[20] M. A. M. Bhuiyan, N. Amin, and K. Sopian, "Effects of absorber and window layer thickness on CdS/CdTe thin film solar cells from numerical analysis by SCAPS 1D," in Proceedings of the IEEE Regional Student Conference on Research and Development (SCOReD '08), p. 210, UTM, Johor, Malaysia, 2008.

[21] M. A. Matin, N. Amin, A. Zaharim, and K. Sopian, "Ultra thin high efficiency CdS/CdTe thin film solar cells from numerical 
analysis," in Proceedings of the 8th WSEAS International Conference on Nonlinear Analysis, Nonlinear Systems and Chaos (NOLASC '09), pp. 338-344, La Laguna, Spain, July 2009.

[22] M. A. Matin, N. Amin, A. Islam, K. Sopian, and K. K. Chong, "Effect of structural variation in cadmium telluride thin film solar cells from numerical analysis," in Proceedings of the 24th European Photovoltaic Solar Energy Conference, pp. 3072-3076, Hamburg, Germany, 2009.

[23] P. Mahawela, G. Sivaraman, S. Jeedigunta et al., "II-VI compounds as the top absorbers in tandem solar cell structures," Materials Science and Engineering B, vol. 116, no. 3, pp. 283-291, 2005.

[24] M. A. Matin, N. Amin, A. Zaharim, and K. Sopian, "A study towards the possibility of ultra thin Cds/CdTe high efficiency solar cells from numerical analysis," WSEAS Transactions on Environment and Development, vol. 6, no. 8, pp. 571-580, 2010. 

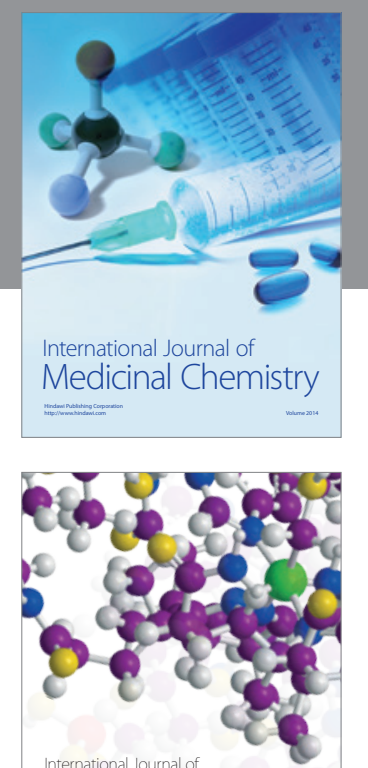

\section{Carbohydrate} Chemistry

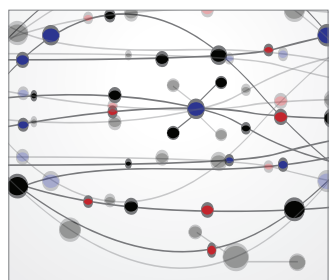

The Scientific World Journal
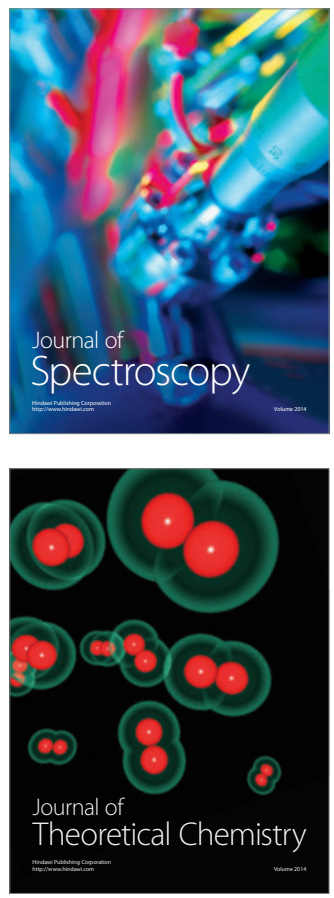
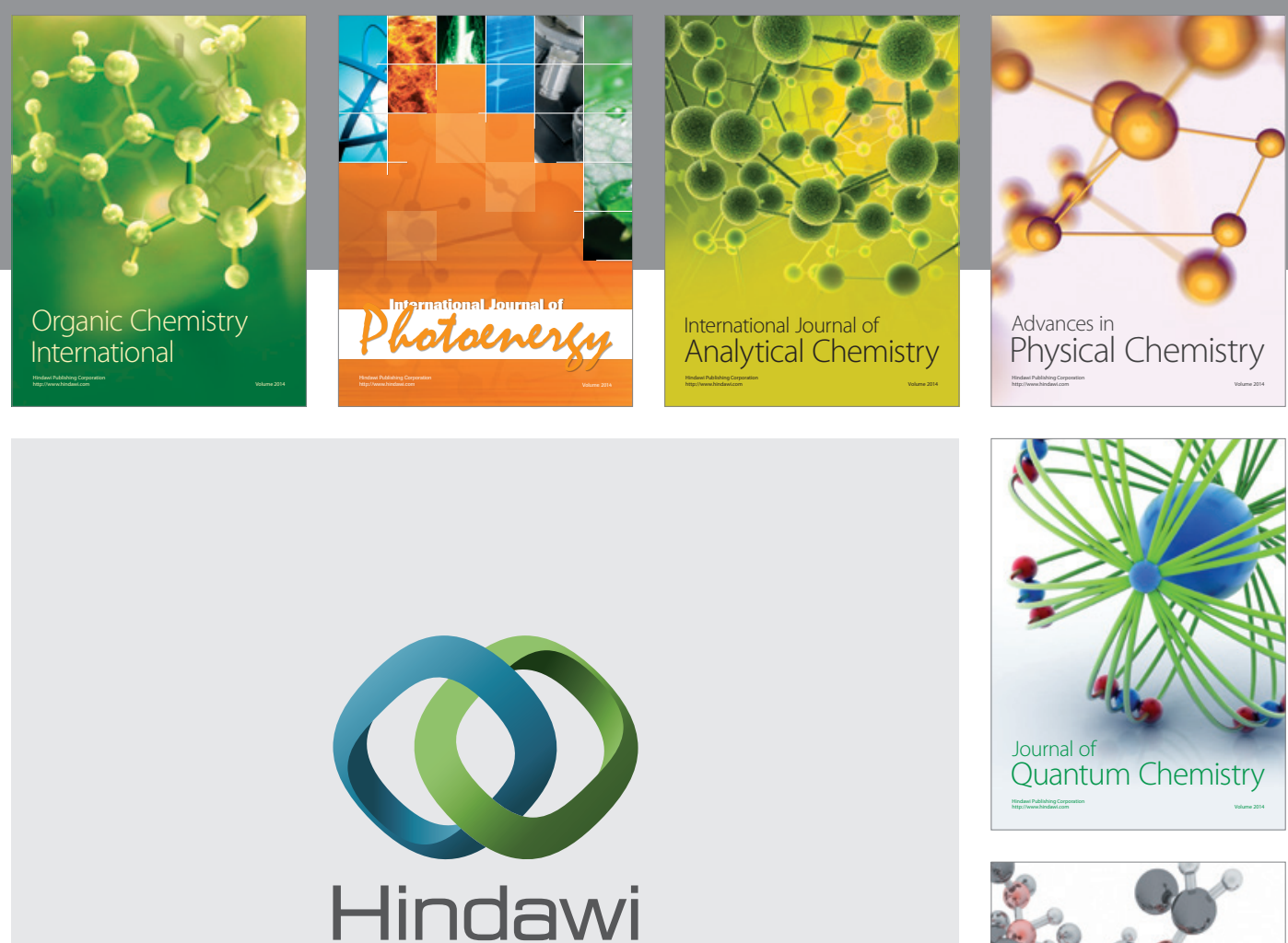

Submit your manuscripts at

http://www.hindawi.com

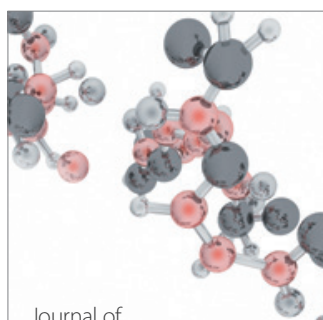

Analytical Methods

in Chemistry

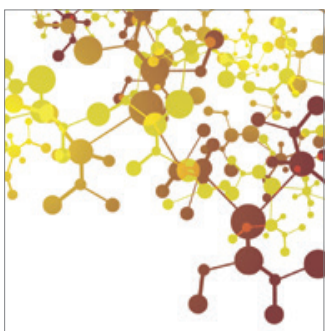

Journal of

Applied Chemistry

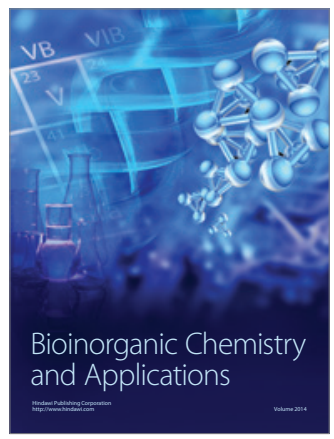

Inorganic Chemistry
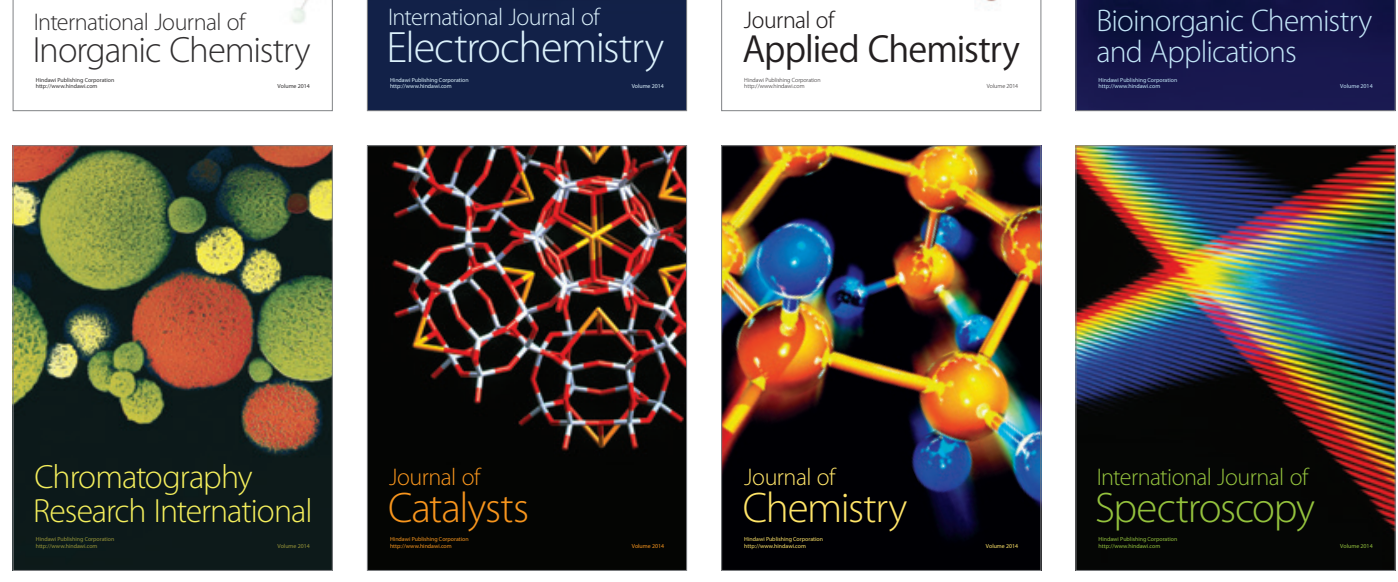